\title{
Searching for a Mythical Wholeness but Never Finding It
}

\author{
Daniel Chirot
}

Published online: 4 October 2011

(C) Springer Science+Business Media, LLC 2011

There is a long tradition among intellectuals now going back at least two centuries of lamenting the loss of community, authenticity, and wholeness that was supposed to exist at some time in the past. Commenting on the progress that led to "Western industrial-scientific society" Robin Fox summarizes this feeling by writing, "The cost was, as early sociologists taught us, the dissolution of social bonds with the growth of individualism and the isolation of the individual." There is indeed a lot of this in Marx and Durkheim, though perhaps somewhat less in Weber who was more worried about the transformation of Puritan asceticism into commercial excesses than about alienation or anomie.

It is less clear if the most often mentioned dead philosopher in Fox's essay, Nietzsche, felt that way. He certainly had considerable contempt for successful liberal democracy as it was practiced in his day in English speaking countries. In Beyond Good and Evil he wrote that the English were "profoundly mediocre" and that their great Enlightenment liberal philosophers John Locke and David Hume were capable only of "mechanical stultification of the world" while British scientists produced little more than "narrowness, aridity, and industrious carefulness." Nietzsche also wrote in Genealogy of Morals that Germany should unite with autocratic Russia to become masters of the world, and to give up "the English principle of the people's right of representation." Above all, he added, "No American future." What Nietzsche seemed to miss was the heroic ancient (but highly mythologized) Greek way, which

\section{Chirot $(\bowtie)$}

Henry M. Jackson School of International Studies,

University of Washington,

Box 353650, Seattle, WA 98195-3650, USA

e-mail: chirot@u.washington.edu is not quite the same thing as the warm pre-modern village bound together by comforting and beloved social bonds. It is unfortunate that he did not live to see what the "heroic" first half of the twentieth century looked like or what happened when Hitler and Stalin joined hands briefly to divide up Europe from 1939 to 1941 and what their less arid "sciences" led to. Never mind. We can still admire Nietzsche's hatred of democracy and progress as a clever way to disparage dull democracy and boring bourgeois comfort.

Fox's essay tries to bring together all of the various complaints about the modern West, be they esthetic, moral, religious, or social, and then combine this with some biology to show that however rational and advanced we try to be, our original, inborn and non-rational impulse to be both communal and heroic breaks through. This is an everlasting problem because these two drives are contradictory. Even worse, contemporary American society, and the West in general, is afflicted by a rational, market driven individualism that denies both aspects of humanity.

Since Western, that is to say European societies have been on a downward path toward mediocrity and alienation for a long time according to critics, it is astounding that we have survived at all. Even more astounding is that the rising power in the East, China, has wholeheartedly adopted the rampant commercialism and narrow, "arid" science of the Western Enlightenment. Perhaps all that will save them is that even if they have dropped all pretense of being wedded to communal solidarity and have a rapidly rising degree of inequality as high as that of the United States (but far higher than Western Europe's) at least so far they have left out the silly liberal fondness for democracy and individual political rights.

There is a lot of brilliant scholarship, profound philosophizing, and historical precedent behind the complaints 
about the inauthenticity of modern Western society, and it is nice to see as eminent an anthropologist as Robin Fox tackling them. It is therefore with some trepidation that I have to conclude that most of this is nonsense.

Pre-industrial village societies were anything but warm and fuzzy places. They were culturally repressive, tolerated little deviance, and in the overwhelming majority of agrarian states they were subjected to the harsh rule of irresponsible nobles, kings, and emperors who taxed them, stole from them, and rarely hesitated to make their lives miserable by inflicting endless wars on them. Slavery or some kind of serfdom or debt peonage were common, and most peasants lived in vermin infested, miserable squalor. Towns were somewhat better in some ways except that they were even more disease ridden and had higher death rates than the villages. Guilds and other associations of rich merchants were run for the benefit of small elites. Religion, aside from a few learned centers whose literate commentaries were inaccessible to the vast majority of people, was a matter of magical incantations and attempts to frighten the masses into submission. There were, to be sure, periodic holidays in which people were allowed to briefly flee the repression and crushing burden of work to which they were subjected, but on the whole, the reason most of this misery was accepted was because few people had any choice.

One of the most startling developments in all modernizing societies, starting during early industrializing decades in Europe, and then spreading extraordinarily quickly to the rest of the world in the second half of the twentieth century, was the speed with which so many people fled their villages for cities as soon as they had a chance to do so. It wasn't just that they were cruelly forced off the land by harsh market conditions, but that especially the young saw an opportunity to escape from the unpleasantness of traditional morality, never ending hard labor, and lack of opportunity in their villages.

Fox comments on, among other things, rising crime rates caused by the rise of Western individualism. Indeed, early industrial cities did have astonishingly high crime rates, as do most large cities in Africa today, but in economically more advanced Western societies crime rates are well below what they once were. And lest anyone forget, the reason why nicely preserved, lovely European old towns had walls around them was to protect themselves from pervasive banditry and violence in those nice old days when individualism was less rampant. As it is, even with the crime, slums, and brutality that exist in many urban centers in Africa, parts of Asia, and Latin America, life there continues to be more attractive than in the presumably more communally authentic countryside.

It may be that life for pre-agrarian hunters and gatherers was somewhat better than for their peasant descendants, but whether or not this was the case is irrelevant because by about three thousand years ago the vast majority of humans were already peasants living in agrarian states. As for the Greek cities, remarkable as some of them were for their philosophy and science, even the most democratic, Athens, was run by a minority of the adult males while most of the populations consisted either of slaves or nominally free but entirely disenfranchised women. Sparta, the most "heroic" of the Greek states was far worse, depending on a large slave population and dedicated to endless war.

Fox's contemporary guiding light is Frances Fukuyama. Fukuyama is one of the major thinkers of our age, and his books are well worth reading and analyzing. Fox's understanding of Fukuyama is certainly much better than some of the shallow commentary about the book that made him famous, The End History and the Last Man. (Actually, it was the article on this that caused a sensation, and the more profound book came out later.) Coming from an intellectual tradition that was highly skeptical of modernity, Fukuyama was never the simple minded American triumphalist many of his fans and detractors thought they saw when he equated the fall of communism with "the end of history." Rather, as Fox suggests, that work was quite pessimistic, and more Nietzschean than the sunny American political elite's naive belief that the events of 1989 proved that the world was heading toward universal American democratic capitalism. Yet, we can question Fukuyama the way we can other critics of prosperous liberal modernity.

Toward the end of The End of History, Fukuyama wrote about Eastern Europe's recent liberation from communism in the bleakest of terms. Speaking of the Romanians who overthrew Ceausescu, the Chinese demonstrators of 1989 in Tiananmen Square, the Lithuanians who stood up to Russians to regain their independence, and the Russians who defended Yeltsin against the attempted coup of 1991, Fukuyama labeled them, "...the most free and therefore the most human of beings." But then he added that after succeeding, as they did (except for the Chinese), all they could expect was to gain dishwashers, VCRs, and private automobiles which would abolish the possibility of their ever being as free and human as when they were struggling against slavery. True enough, especially the young caught up in the excitement of revolutionary activity who rarely regain that sense of elation, but what this has to do the general well being of society is somewhat of a mystery.

What, exactly, is wrong with wanting to be economically secure and free of the endless, petty humiliations one suffers when dealing with the bureaucracies of corrupt autocracies? Should those rare moments when we feel exultation because we have participated in a revolution, or as Fox aptly points out, watched our favorite football team win an unlikely victory, provide a blueprint for a good society? Does the search for such moments justify the 
contempt critical intellectuals have long had for the material successes of modernity? Let them, if they are not too old, join the special forces or try sky diving instead of inflicting on the rest of us pernicious doctrines about the need to recapture some combination of lost community and heroism.

It is not that Fox fails to recognize the dilemma. That is what his essay is about. But he underplays the noxious outcomes. Perhaps nothing illustrates this better than thinking about the Martin Heideger problem. To greatly simplify, what made Heidegger sympathize with the Nazis was not anti-Semitism but his lifelong belief in the need to reconstitute community, the volksgmeinschaft dominated by more heroic figures than Weimar politicans, and his dismissal of individual rights, of liberal democratic values, and of egalitarian ideals. Very few of his followers, including Jean-Paul Sartre (who of course insisted he was on the left instead of the right and who claimed to be opposed to Heidegger), deviated from this hatred of the virtues of the Enlightenment, and consequently, contempt for the accomplishments of dull, materialistic progress, and particularly dislike of America. The same can be said for much of the entire post-modernist movements that sprang from French admirers of Heidegger, including Michel Foucault and the Belgian Paul de Man. One could claim to be on the left as well as the right - it was, after all, merely a matter of convenience because for decades after 1945 it was just too unfashionable to be on the right — but the outcome was the same.

This may appear to be going too far. Neither Robin Fox nor Frances Fukuyama is a proponent of totalitarian doctrines, and Fukuyama reluctantly praises liberal democracy despite its lack of excitement and communal bonds. But we need to think carefully about falling into the trap of criticizing liberal progress because it results in weakening tradition, making more people comfortable, and routinizing politics.
So, what is Fox's solution to this problem of combating the breakdown of community and boredom in the modern world? He likes the idea of having symbols to worship and approves of royal families. He praises the Queen of England (whose offspring generate the same kind of publicity as philandering movie stars), the Emperor of Japan (General MacArthur's everlasting and shameful error - Hirohito should have been hung as a Class A war criminal), and the King of Spain (whom Franco wrongly hoped would extend Franco's own stultifying authoritarian Catholic rule). He likes the idea of a civil religion to complement civil society, as August Comte proposed. And he closes with an enigmatic reference to modern genetic science, as if showing that we are all descended from a small group of Africans 60,000 years ago is a good basis for resolving the problems of modernity and our divided natures.

This is not really meant as an attack against the Fox essay, though it may sound like it. Rather, what I mean to say is that after a couple of centuries of bemoaning the problems of what modernization has wrought, it is time to reconsider what we mean by the human need for communal solidarity, and to ask ourselves if this is really lacking in the most advanced societies, or if instead it is more a problem cooked up by restless intellectuals than by society at large. And perhaps it is also a good moment to study why so many brilliant, influential intellectuals dissatisfied with the Enlightenment philosophies that gave us modern liberal progress have cooked up such destructive political ideologies on both the left and the right. Then, as Fox proposes, we can get a fresh start on how to construct a new and better way of dealing with the human contradictions he eloquently addresses.

Daniel Chirot is Job and Gertrud Tamaki Professor of International Studies at the University of Washington. His most recent books are Contentious Identities (2011), a revised second edition of How Societies Change (2011), and a second edition of the co-authored Why Not Kill Them All? (2010). 